UDC 332.122.62

(C) 2016

I. Chekhova, Candidate of Economics Sciences Institute of Oilseeds of NAAS

S. Chekhov, Candidate of Economics Sciences

Research Station of Aerial Oil and Low-Crop Agricultural Crop Sciences

\title{
ANALYSIS OF PRODUCTION OF OILY CROPS IN ZONE OF STEPPE
}

The purpose. To analyze dynamics and rates of changes of indexes of production of oily crops, price items of sunflower, rape, soya bean, to determine structure and differences of production of oily crops in zone of Steppe of Ukraine. Methods. System generalization, abstract-logical, economic-statistical, graphical, comparative. Results. They analyzed dynamics and rates of changes of indexes of production of sunflower, rape, soya bean for the period 2012 - 2014 in zone of Steppe of Ukraine and by oblasts. It is fixed that the area under soya bean decreased for $14 \%$, under sunflower - for $5 \%$, while under rape - increased in 3,4 times.

Conclusions. There is a transfer to an intensive type of production of oily crops. The basic oily crop in steppe zone, as well as in Ukraine is sunflower. Overgrowth of its industrial volumes - due to increase of productivity, and soya bean and rape - due to increase of productivity and dilating of areas. The increase yield due to use of new promising varieties of seeds of oily crops is the major factor of the further increase of production of oily crops in zone of Steppe of Ukraine. The structure of production of oily crops in zone of Steppe and in Ukraine has unessential differences with predominance of a share of sunflower.

Key words: production of sunflower, soya bean, rape, market of oily crops, price items of oily crops, framework of production.

Formulation of the problem. Over the last decade, an oilseed is among the most profitable crops. The main factors in their favor, favor the price of the agricultural market, steady demand for commodity products, developed infrastructure, steel sales trends.

The purpose of the article - to analyze the performance of production of oilseeds in the steppe zone, the prices of sunflower, rapeseed, soybean, to define the structure of the production of oilseeds in the Steppe zone of Ukraine. 
The purpose of the article - to analyze the performance of production of oilseeds in the steppe zone, the prices of sunflower, rapeseed, soybean, to define the structure of the production of oilseeds in the Steppe zone of Ukraine.

Analysis of recent research and publications. The theory of formation and development of agricultural markets represented in the research of scholars such as M. Malik [3], A. Kovalenko [2], N. Pavlenchik [5], A. Sakva [6], A. Maslak [4], G. Timofeyeva [7]. The issue of pricing for agricultural products covered thorn in the works of A. Shpyhak [13], L. Shkvarchuk [12], A. Oliynik [12].

Presenting main material. Production of main oil crops in the steppe zone of Ukraine for 2013-2014 years decreased by $1.2 \mathrm{mln}$. tons, or $14 \%$ (from 8.3 to $7.1 \mathrm{mln}$. Tons) by reducing the production of sunflower by 1.1 million tons, or $16 \%$ (from 6.9 to $5.8 \mathrm{mln}$. tons) and rapeseed - by 82.8 ths. tons, or by $10.5 \%$ (from 785 to 702 thous. tons). Dynamics of production of soybeans was positive - the increase amounted to 30.8 thousand. tons or $5.3 \%$ (from 585 to 615.9 ths. tons).

The main reasons are, firstly, the reduction of the area under sunflower seed by 54 thousand. ha or $1.5 \%$ (from 3.6 to $3.5 \mathrm{mln}$. ha) and rapeseed by 24.7 thousand. ha or at $6.3 \%$ (from 390 to 365.4 thousand. ha), and secondly, reducing the yield of sunflower with $18.4 \mathrm{c} /$ ha to 16.3 c/ha, soybean - from 18.1 to $18 \mathrm{c} / \mathrm{ha}$. The average level of productivity of oilseeds in the steppe zone fell last year from $18.6 \mathrm{c} /$ ha to $17.9 \mathrm{c} / \mathrm{ha}$, the highest yield recorded by rape - $19.4 \mathrm{c} /$ ha (Table 1 ). Note, that the average yield of oilseeds in practical use less potential for $30-50 \%$. According to experts, the growth rate of the yield of oilseeds in Ukraine repeated global trends a decade ago.

1. Dynamics of production of oilseeds in the Steppe zone of Ukraine in 2013-2014

\begin{tabular}{|l|l|l|l|}
\hline Culture & Area, thous. Ha & Gross, ths. Tons & Productivity, c/ha \\
\hline
\end{tabular}




\begin{tabular}{|c|c|c|c|c|c|c|c|c|c|}
\hline & $\begin{array}{c}2013 \\
\text { p. }\end{array}$ & $\begin{array}{c}2014 \\
\text { p. }\end{array}$ & $\begin{array}{c}\text { Chang } \\
\text { e, \% }\end{array}$ & $\begin{array}{c}2013 \\
\text { p. }\end{array}$ & $\begin{array}{c}2014 \\
\text { p. }\end{array}$ & $\begin{array}{c}\text { Chang } \\
\text { e, \% }\end{array}$ & $\begin{array}{c}2013 \\
\text { p. }\end{array}$ & $\begin{array}{c}2014 \\
\text { p. }\end{array}$ & $\begin{array}{c}\text { Chang } \\
\text { e (+,-) }\end{array}$ \\
\hline Sunflower & 3584,4 & 3530,5 & 98,5 & 6924,3 & 5814,5 & 84,0 & 18,4 & 16,3 & $-2,1$ \\
\hline Rapeseed & 390,1 & 365,4 & 93,7 & 784,6 & 701,8 & 89,5 & 19,4 & 19,4 & 0 \\
\hline Soybean & 260,4 & 295,4 & 113,4 & 585,1 & 615,9 & 105,3 & 18,1 & 18,0 & $-0,1$ \\
\hline Total: & $\mathbf{4 2 3 4 , 9}$ & $\mathbf{4 1 9 1 , 3}$ & $\mathbf{9 9 , 0}$ & $\mathbf{8 2 9 4 , 0}$ & $\mathbf{7 1 3 2 , 2}$ & $\mathbf{8 6 , 0}$ & $\mathbf{1 8 , 6}$ & $\mathbf{1 7 , 9}$ & $\mathbf{- 0 , 7}$ \\
\hline
\end{tabular}

Such indicators as now in Ukraine observed in Europe in 2000-2005. The main reason for this development is the slow rate of use of modern technological approaches and high-performance varieties and hybrid seeds. Therefore, what has long been used in Europe for Ukraine is something absolutely new. This is evidence of a significant shortfall in the harvest of oilseeds and points to the prospect of further development.

Analysis of performance of sunflower in steppe zone of Ukraine (Tab. 2) for the period 2013-2014 on regions was showed, that the reduction in the area under sunflower was due to exclusion ranges growing in the Crimea (-80 thousand ha), its slight reduction Lugansk (-67.1 thousand ha), Donetsk (-36.7 thousand ha), Odessa (-9.1 thousand ha) areas. Thus in most areas of the territory were expanding the area of $5 \%$ (Zaporizhya, Mykolaiv, Kherson region.) almost 8\% - in Dnipropetrovs'k, Kirovograd region. The biggest sunflower crops last year concentrated in Zaporizhya (578 thousand $\mathrm{Ha}$ in 2014 against 552.6 thousand ha in 2013), Dnipropetrovs'k (558 thousand $\mathrm{Ha}$ in 2014 against 515.8 thousand. ha in 2013) Kirovograd region (544 thousand ha in 2014 against 507.1 thousand ha in 2013).

Performance sunflower fell by $2.1 \mathrm{c} / \mathrm{ha}$ on average, the highest in the Dnipropetrovs'k region (From 22.7 to $16.9 \mathrm{c} / \mathrm{ha}$ ) and Mykolaiv region (from 21.5 to $15.9 \mathrm{c} / \mathrm{ha}$ ). The highest productivity of sunflower is in the Kirovograd region (21.4 c/ha in 2014 against 24.2 c/ha in 2013). 


\section{Production of sunflowers in the steppe zone of Ukraine in 2013- 2014.}

\begin{tabular}{|c|c|c|c|c|c|c|c|c|c|}
\hline \multirow[b]{2}{*}{ Region } & \multicolumn{3}{|c|}{ Area, thous. Ha } & \multicolumn{3}{|c|}{ Gross, ths. Tons } & \multicolumn{3}{|c|}{ Productivity, c/ha } \\
\hline & 2013 & 2014 & $\begin{array}{c}\text { Chang } \\
\text { e, } \%\end{array}$ & 2013 & 2014 & $\begin{array}{c}\text { Chang } \\
\text { e } \%\end{array}$ & $\begin{array}{c}201 \\
3\end{array}$ & $\begin{array}{c}201 \\
4\end{array}$ & $\begin{array}{c}\text { Chang } \\
\text { e } \\
(+,-)\end{array}$ \\
\hline Crimea & 83,8 & - & - & 109,3 & - & - & 13,1 & - & - \\
\hline $\begin{array}{c}\text { Dnipropetrov } \\
\text { sk }\end{array}$ & 515,8 & 558,1 & 108,2 & $\begin{array}{c}1172 \\
8 \\
\end{array}$ & 945,3 & 80,6 & 22,7 & 16,9 & $-5,8$ \\
\hline Donetsk & 445,1 & 408,4 & 91,76 & 778,2 & 732,8 & 94,2 & 17,5 & 17,9 & $+0,4$ \\
\hline Zaporizhia & 552,6 & 578,1 & 104,6 & 921,3 & 769,7 & 83,6 & 16,7 & 13,3 & $-3,4$ \\
\hline Kirovograd & 507,1 & 544,2 & 107,3 & $\begin{array}{c}1229 \\
1\end{array}$ & $\begin{array}{c}1162 \\
3\end{array}$ & 94,6 & 24,2 & 21,4 & $-2,8$ \\
\hline Lugansk & 365,9 & 298,8 & 81,7 & 639,5 & 531,5 & 83,1 & 17,5 & 17,8 & $+0,3$ \\
\hline Mykolaiv & 437,5 & 459,1 & 104,9 & 939,9 & 728,9 & 77,6 & 21,5 & 15,9 & $-5,6$ \\
\hline Odessa & 380,5 & 371,4 & 97,6 & 777,2 & 672,7 & 86,6 & 20,4 & 18,1 & $-2,3$ \\
\hline Herson & 296,1 & 312,4 & 105,5 & 356,9 & 271,3 & 76,0 & 12,1 & 8,7 & $-3,4$ \\
\hline STEPPE: & $\begin{array}{c}3584 \\
4\end{array}$ & $\begin{array}{c}3530 \\
5\end{array}$ & 98,5 & $\begin{array}{c}6924 \\
3\end{array}$ & $\begin{array}{c}5814 \\
5\end{array}$ & 84,0 & 18,4 & 16,3 & $-2,1$ \\
\hline
\end{tabular}

Reducing the gross harvest of sunflower occurred in all areas without exception. The largest drop in gross fees in Herson (- 24\%) and Mykolaiv region. (- $22.6 \%)$. Leaders of sunflower production in the steppe zone of Ukraine: Kirovograd region (1.1 million tons), Dnipropetrovs'k region (945 thousand tons), Donetsk region (733 ths. tons).

Analysis of performance of rapeseed in the steppe zone of Ukraine (Tab. 3) for the period 2013-2014 on regions was showed a strong tendency to reduce the area under rapeseed by eliminating arrays growing in the Crimea (-8 thousand Ha), reduction in Dnipropetrovs'k (-20.2 thousand ha) and Zaporozhye (-8 thousand ha) areas. The expansion of crops of rape was registered in Odessa (24.8 thousand Ha), Donetsk (2.2 thousand $\mathrm{Ha}$ ), Lugansk ( 0.5 thousand $\mathrm{Ha}$ ) areas. Major crops of rapeseed are concentrated in Odessa (from 120 thousand ha in 2014 to 95.5 
thousand ha in 2013) and Dnipropetrovs'k (57.6 thousand ha in 2014 to 77.8 thousand ha in 2013).

3. Production of rapeseed in the steppe zone of Ukraine in 20132014

\begin{tabular}{|c|c|c|c|c|c|c|c|c|c|}
\hline & \multicolumn{3}{|c|}{ Area, thous. Ha } & \multicolumn{2}{c|}{ Gross, ths. Tons } & \multicolumn{3}{c|}{ Productivity, c/ha } \\
\cline { 2 - 11 } Region & $\mathbf{2 0 1 3}$ & $\mathbf{2 0 1 4}$ & $\begin{array}{c}\text { Change, } \\
\text { \% }\end{array}$ & & $\mathbf{2 0 1 3}$ & $\mathbf{2 0 1 4}$ & $\begin{array}{c}\text { Change, } \\
\%\end{array}$ & & $\mathbf{2 0 1 3}$ \\
\hline Crimea & 8,4 & - & - & 16,4 & - & - & 19,4 & - & - \\
\hline Dnipropetrovsk & 77,8 & 57,6 & 74,0 & 161,4 & 98,9 & 61,3 & 20,7 & 17,2 & $-3,5$ \\
\hline Donetsk & 6,5 & 8,7 & 134,0 & 14,2 & 17,5 & 123,2 & 21,9 & 20,0 & $-1,9$ \\
\hline Zaporizhya & 38,8 & 30,6 & 78,9 & 71,7 & 47,3 & 65,9 & 18,5 & 15,5 & -3 \\
\hline Kirovograd & 52,3 & 49,5 & 94,7 & 126,0 & 109,3 & 86,8 & 24,1 & 22,1 & -2 \\
\hline Lugansk & 1,4 & 1,9 & 135,7 & 1,9 & 4,3 & 226,3 & 13,6 & 22,9 & $+9,3$ \\
\hline Mykolaiv & 50,7 & 44,5 & 87,8 & 97,2 & 92,1 & 94,8 & 19,2 & 20,7 & $+1,5$ \\
\hline Odessa & 95,5 & 120,3 & 125,9 & 196,1 & 251,1 & 128,0 & 20,5 & 20,9 & $+0,4$ \\
\hline Herson & 58,7 & 52,3 & 89,1 & 99,8 & 81,3 & 81,5 & 17,0 & 15,5 & $-1,5$ \\
\hline STEPPE: & 390,1 & 365,4 & 93,7 & 784,6 & 701,8 & 89,5 & 19,4 & 19,4 & 0 \\
\hline
\end{tabular}

Productivity of rapeseed in the average zone remained unchanged at $19.4 \mathrm{c} / \mathrm{ha}$ with an overwhelming negative trend in the region. The highest level of productivity within 2 years of rape registered in Kirovograd region (21.1 c/ha in 2014 against $24.1 \mathrm{c} / \mathrm{ha}$ in 2013), Odessa region (20.9 c/ha in 2014 against $20.5 \mathrm{c} / \mathrm{ha}$ in 2013 ).

These changes have led to a reduction in gross harvest of rapeseed in most areas of the steppe zone. The highest rates fall harvest took place in Dnipropetrovs'k (-38.7\%) and Zaporizhya (-34.1\%) regions. Leaders for the production of rapeseed in the steppe zone of Ukraine: Odessa (251.1 thousand tons), Kirovograd region (109.3 thousand tons), Dnipropetrovs'k region (98.9 ths. tons).

Analysis of performance of soybean in the steppe zone of Ukraine (Tab. 4) for the period 2013-2014 in the regions showed a strong tendency 
to build up areas, despite the exclusion arrays growing in the Crimea (-13.9 thousand. ha) and Lugansk region (-0.8 thousand ha). In all other areas there was expansion of soybean crops. The highest growth rates showed the Odessa area (+67.2\%) and Zaporizhya (+ 40.3\%) region.

4. Production of soybean in the steppe zone of Ukraine in 20132014

\begin{tabular}{|c|c|c|c|c|c|c|c|c|c|}
\hline \multirow[b]{2}{*}{ Region } & \multicolumn{3}{|c|}{ Площа, тис. га } & \multicolumn{3}{|c|}{ Валовий збір, тис. т } & \multicolumn{3}{|c|}{$\begin{array}{c}\text { Урожайність, } \\
\text { ц/га }\end{array}$} \\
\hline & $\begin{array}{c}2013 \\
\text { p. }\end{array}$ & $\begin{array}{c}2014 \\
\text { p. }\end{array}$ & $\begin{array}{c}\text { 3міни, } \\
\%\end{array}$ & $\begin{array}{c}2013 \\
\text { p. }\end{array}$ & $\begin{array}{c}2014 \\
\text { p. }\end{array}$ & $\begin{array}{c}\text { 3міни, } \\
\%\end{array}$ & $\begin{array}{c}2013 \\
\text { p. }\end{array}$ & 2014p. & $\begin{array}{c}\text { 3міни, } \\
(+,-)\end{array}$ \\
\hline Crimea & 13,9 & - & - & 33,6 & - & - & 24,2 & - & - \\
\hline Dnipropetrovsk & 4,7 & 5,8 & 123,4 & 6,2 & 6,9 & 111,3 & 13,4 & 11,9 & $-1,5$ \\
\hline Donetsk & 0,9 & 0,9 & 100,0 & 0,5 & 0,7 & 140,0 & 6,2 & 7,8 & 1,6 \\
\hline Zaporizhya & 7,3 & 10,1 & 140,3 & 20,6 & 27,3 & 133,2 & 28,3 & 27,0 & $-1,3$ \\
\hline Kirovograd & 124,0 & 150,2 & 121,1 & 189,7 & 226,8 & 119,6 & 15,3 & 15,1 & $-0,2$ \\
\hline Lugansk & 0,8 & - & - & 0,8 & - & - & 10,2 & - & - \\
\hline Mykolaiv & 15,2 & 16,4 & 107,9 & 23,0 & 26,9 & 117,0 & 15,1 & 16,5 & $+1,4$ \\
\hline Odessa & 6,4 & 10,7 & 167,2 & 10,0 & 18,5 & 183,2 & 15,7 & 17,3 & $+1,6$ \\
\hline Herson & 87,4 & 101,3 & 115,9 & 300,6 & 308,8 & 102,7 & 34,4 & 30,5 & $-3,9$ \\
\hline STEPPE: & 260,4 & 295,4 & 113,4 & 585,1 & 615,9 & 105,3 & 18,1 & 18,0 & $-0,1$ \\
\hline
\end{tabular}

The biggest soybean crops are concentrated in Kirovograd (150.2 thousand ha in 2014 to 124 thousand ha in 2013) and Herson (101.3 thousand ha in 2013 to 87.4 thousand ha in 2013) areas. Productivity of soybean area average remained almost unchanged at $18 \mathrm{c} /$ ha. The highest level recorded in soybean yield Herson (30.5 c/ha in 2014 against 34.4 c/ha in 2013) and Zaporizhya (27 c/ha in 2014 against $28.3 \mathrm{c} / \mathrm{ha}$ in 2013 p.) fields through irrigation.

Gross of soybean in the steppe zone of Ukraine increased by 585 ths. tons to 615.9 thousand tons, or $5.3 \%$. The highest growth rates registered in Odessa $(+83.2 \%)$, Donetsk $(+40 \%)$ regions. The largest 
soybean crop harvested in Kherson (308.8 ths. tons), Kirovograd (226.8 thousand tons).

Structure of production of oilseeds in the Steppe zone by regions shows the concentration in the production of sunflower in all areas except for the Herson region. Over $70 \%$ of the total area occupied by sunflower oilseeds in Kirovograd and Odessa region, over $80 \%$ - in Mykolayiv and Dnipropetrovs'k region, over 90\% - in Zaporizhya, Donetsk, Lugansk regions. Against the background of the distribution of production areas under oilseeds Kherson region exception where $41 \%$ occupied by sunflower, $47 \%$ - for soybeans, $12 \%$ - for rapeseed (Fig. 1).

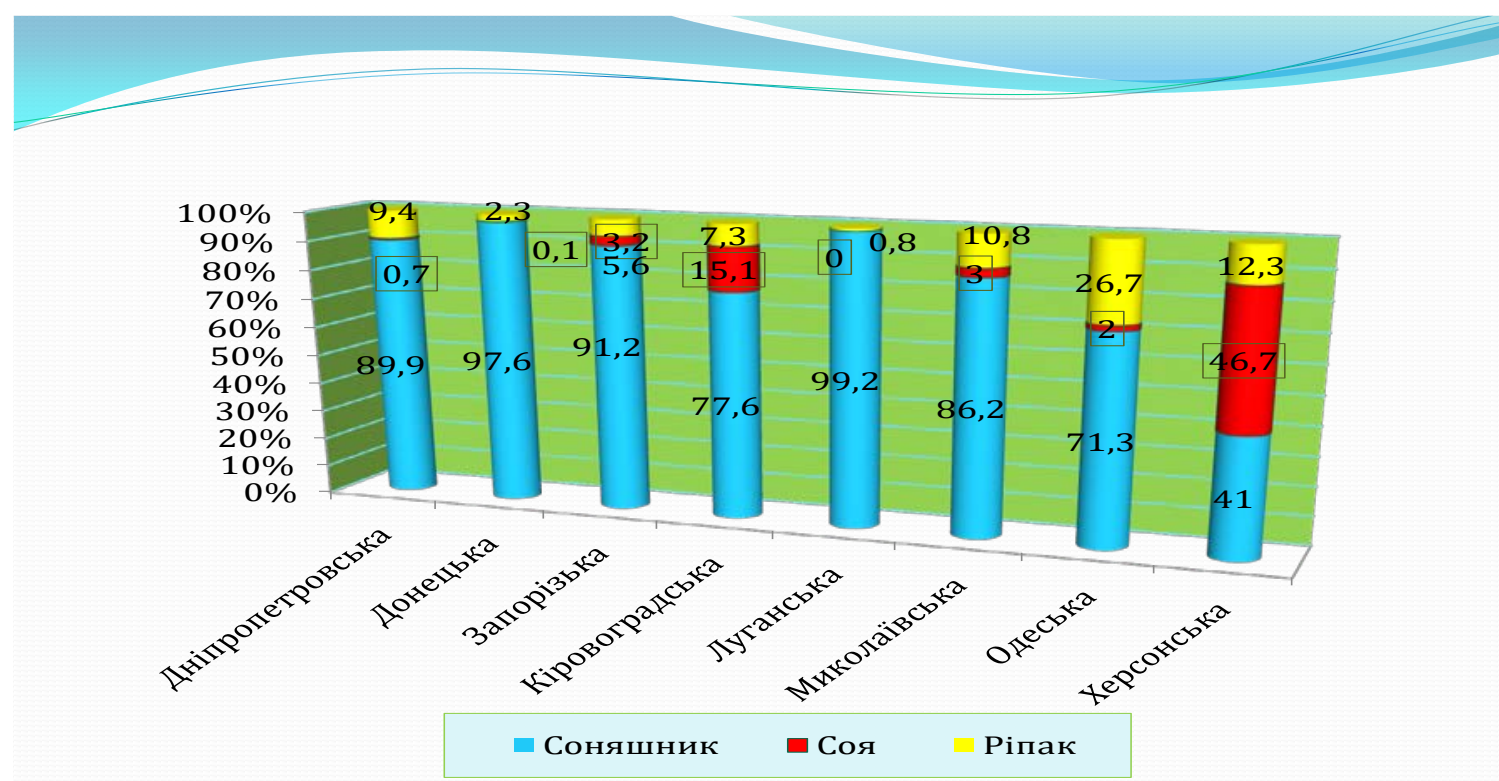

Fig. 1. The structure of the production of oilseeds in the steppe zone in regions in 2014.

Thus, the main oil crops in the steppe zone, still have Sunflower, which occupies more than $84 \%$ in the total oilseeds, followed by rape (8\%) and soybean $(7 \%)$.

Analysis of the prices in the market of oilseeds for the 2013-2015 showed prices growth positions in oilseeds. The most expensive three years is soybean (from 3650-5800 $\mathrm{UAH} / \mathrm{t}$ in 2013 to $7300-9600 \mathrm{UAH} / \mathrm{t}$ in 2015), the second position is sunflower (from 2900-5000 UAH/t in 2013 to 
7100- $9650 \mathrm{UAH} / \mathrm{t}$ in 2015), third - rapeseed (of 3200-4400 UAH/t in 2013 to $6100-7500 \mathrm{UAH} / \mathrm{t}$ in 2015) (Fig. 2).

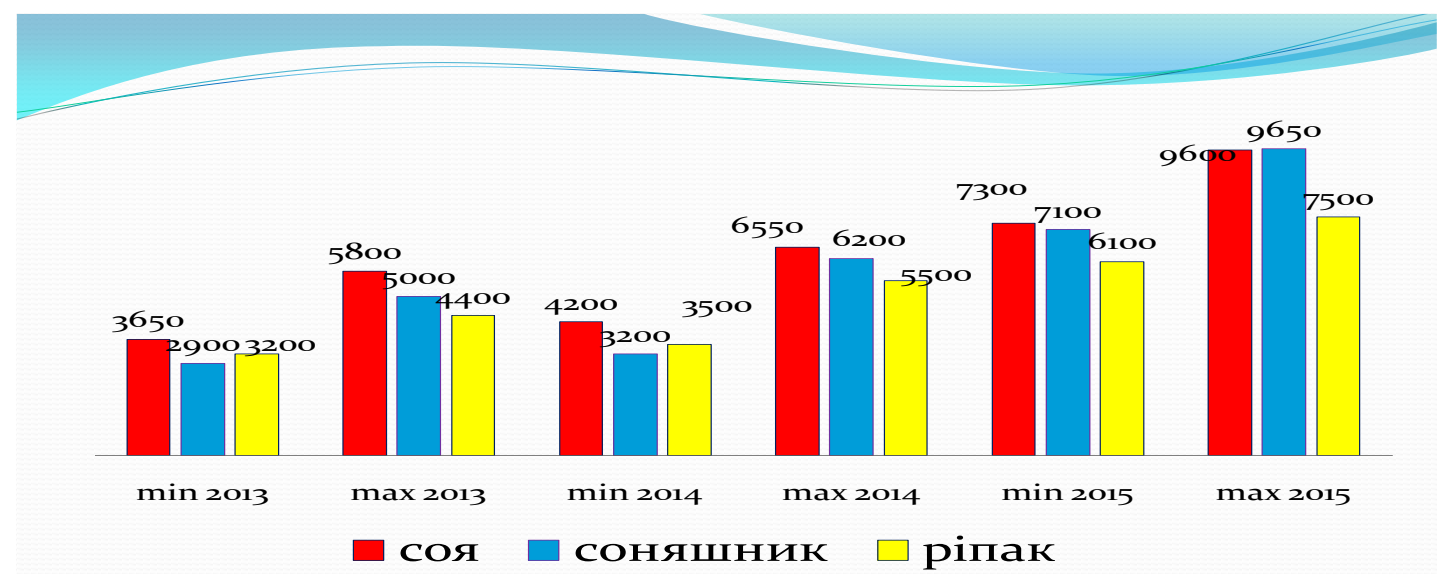

Fig. 2. The prices on the market of oilseeds in 2013-2015.

It is important to note that during this period the price of soybeans increased 2-fold, or at $3700 \mathrm{UAH} /$ ton, sunflower - 2.4 times, or by 4400 $\mathrm{UAH} / \mathrm{t}$, rapeseed - 2 times, or $3000 \mathrm{UAH} / \mathrm{t}$, respectively, the growth costs of cultivation. So, just last year the cost of sunflower production increased from 3500 to $6000 \mathrm{UAH} / \mathrm{t}$, or 1.7 times, soybeans - from 4000 to 6000 $\mathrm{UAH} / \mathrm{t}$, or 1.5 times, rapeseed - from 5000 to $6500 \mathrm{UAH} / \mathrm{t}$, or 1.3 times. The price of the agricultural market and is a significant motivating factor in the decision on forming the rotation in favor of oilseed crops in farms of all forms of ownership.

Conclusions and recommendations for further research. Production of main oil crops in the steppe zone of Ukraine for 2013-2014 years decreased by $1.2 \mathrm{mln}$. tons, or $14 \%$ (from 8.3 to $7.1 \mathrm{mln}$. tons) by reducing the production of sunflower by 1.1 million . $t$, or $16 \%$ (from 6.9 to $5.8 \mathrm{mln}$. tons) and rapeseed - by 82.8 ths. tons, or by $10.5 \%$ (from 785 to 702 ths. tons).

Leaders for the production of sunflower are: Kirovograd (1.1 million tons), Dnipropetrovs'k (945 thousand tons), Zaporizhya (733 thousand tons) region. For rapeseed: Odessa (251.1 ths. Tons), Kirovograd (109.3 
ths. Tons). The largest harvested of soybean in Kherson (308.8 ths. Tons), Kirovograd (226.8 thousand tons).

Analysis of the price situation in the market of oilseeds showed price growth of all positions in oilseeds. The most expensive three years is soy (from 3650-5800 UAH/t in 2013 to 7300-9600 UAH/t in 2015), the second position is sunflower (from 2900-5000 UAH/t in 2013 to $7100-9650 \mathrm{UAH} / \mathrm{t}$ in 2015), third - rapeseed (of 3200-4400 UAH/t in 2013 to 6100-7500 UAH/t in 2015).

According to experts in the field of Ukraine will further increase soybean crops by reducing the area under sunflower and rapeseed. In the steppe zone of these changes will be slower by a factor of climatic conditions and lack of irrigation land for a sharp increase soybean.

\section{Bibliography}

1. Goysyuk L.V. Formation prices for rapeseed. [E. resource]. Access: http://khntusg.com.ua.

2. Kovalenko O.V. New markets as a result of short-term needs of society.//Agrosvit. - 2015. - № 15. - P. 35-42.

3. Malik M.Y. Institutes and institutions in the development of the agricultural sector of the economy//Economy AIC. - 2011. -№ 7. - P. 169176.

4. Maslak A. Market of rapeseed: demand exceeds supply//Agribusiness today. - 2011. - № 15-16 (215). - P. 28-32.

5. Pavlenchik N.F. Theoretical basis of justification definitions "The market of agricultural products"//Economics APC. - 2014. -№1. - P. 85-92.

6. Sakva O.V. Formation of the structure of production in the market of oilseeds//Agrosvit. - 2009. - №12. - P. 30-32.

7. Timofeeva G.V. Strategic development of oilseeds production in the region in the conditions of accession to the WTO//Vesnik Volgogr. Gos. Univ. Ser.3, Econ. Ecol. - 2013. - №2 (23). - P. 27-36. 
8. Shkvarchyuk L.A. Price trends in the food market of Ukraine//Economy AIC. - 2010. - №7. - P. 57-63.

9. Shpychyak O.M. Price and pricing on agro food products: teach. guidances. - $\mathrm{K}$.: NNC IAE, 2009. - $238 \mathrm{p}$. 